\title{
FAIR VALUE EMPIRICAL STUDIES: AN OVERVIEW ON ACCONTING RESEARCH LITERATURE
}

\author{
Carmen Giorgiana Bonaci ${ }^{1}$ \\ Adriana Tiron Tudor ${ }^{2}$
}

\begin{abstract}
Our paper develops a literature review on fair value studies. The purpose of the study is to synthesize the main results of accounting research literature empirically approaching fair value measurement. Therefore, our analysis imposes the use of literature review methodology. After briefly introducing the concept of fair value, the first part of the paper follows the shift taking place in accounting paradigms when it comes to accounting models. The main part of the paper discusses empirical studies on fair value by closely analyzing their research design, the employed research methodology and the obtained results. The originality of the paper as well as its contribution consist in offering a comprehensive overview on studies in accounting research literature that analyze fair value accounting through an empirical approach. Discussing the relevance and reliability of such studies further impacts upon the relevance of their results and how they can be used.
\end{abstract}

Key words: Fair value, accounting model, empirical studies, research literature

JEL codes: $M 40$, M41

\section{Introduction}

Starting as a specific remedy for particularities concerning the reporting model for certain financial instruments, fair value has enforced itself as the dominant paradigm in the case of financial evaluations, thus becoming an ever-present notion in the evaluation of various nonfinancial elements. The reporting model based on cost and transaction is becoming obsolete, a new market-based-value one gaining in importance, its implications being quite important for the role and characteristics of financial statements (Matiş and Bonaci, 2008). Compiling this retrospective that focuses on accounting research literature does not specifically aim the discovery of new points of view or new ways of interpreting the theoretical subtleties, but tries to offer a foundation and a conceptual framework meant to ease the conceptualization of the fair-value notion in the current context. Therefore, we have chosen to focus on pros and cons for using fair value in financial reporting, analyzing and clearly delimiting options backed up by theoretical and empirical studies.

Throughout the years, there have been a series of fierce debates on the subject of the need of an evaluation based on current or historic costs, in approach to the matters of assets and debts. In each of the variants, the role of the balance sheet as a source for useful information from a decisional point of view cannot be disputed. The conceptual implications of this idea generate a wider opening towards the fair-value paradigm, which is especially simulated by the specific issues of the accounting of financial instruments. Another key event which has determined the orientation towards the fair-value paradigm is represented by the savings and loans crisis (S\&L Crisis) from the U.S.A., during the 80's. It was this crisis that drew attention on the deficiencies of the historical cost

\footnotetext{
${ }^{1}$ Babeş-Bolyai University, Faculty of Economics and Business Administration, Cluj-Napoca, Romania, e-mail: carmen.bonaci@econ.ubbcluj.ro

2 Babeş-Bolyai University, Faculty of Economics and Business Administration, Cluj-Napoca, Romania, e-mail: adriana.tiron@econ.ubbcluj.ro
} 
system. In the aftermath of those events, the SEC performed a series of normative actions, which determined the FASB (Financial Accounting Standards Board) to develop a standard for accounting the financial instruments at their market value instead of the depreciation cost. Despite its limited goal, this initiative represented an important first step in the evolution of accounting and particularly accounting regulations. Emerging as a specific regulation only for certain types of actions, fair value evaluation has rapidly become the most relevant attribute of financial instruments.

The remainder of our study is organized as follows: a historic retrospective on the change in accounting paradigms is developed based on accounting literature followed by grounding the employed research methodology; developing the analysis is done together with discussing the obtained results and finally presenting some concluding remarks.

\section{Historic retrospective and the change in paradigm}

The current evolution that aims for fair value evaluation, is often characterized as being a change of paradigms (Barlev and Haddad, 2003: 385). A paradigm represents a set of values and beliefs that are share by a certain community. In correspondence, in the financial reporting filed, a paradigm will represent a set of shared values referring to the objectives of financial reporting and the accounting principles needed to reach those goals. This is founded on the formulating of certain assumptions, and, in a characteristic manner, imposes a theoretical validation and foundation. Furthermore, a paradigm in the field of evaluation, assumes an agreement regarding the evaluation attributes necessary for reaching the objectives of financial reporting which were previously mentioned. Once the regulating organizations adopt a certain paradigm corresponding to financial evaluation, this becomes an implicit principle that will guide the direction and elaboration procedures of accounting regulations.

The paradigm of fair value is based on the paradigm of decisional utility, which was highlighted as the official objective of the FASB's accounting regulations and of the common conceptual framework project. However, while the historical cost model results from a bundle of specific influences - which include aspects related to contracting and organizing (Hotlhausen and Watts, 2001) - the evaluation based on fair value has been brought to attention by directly referring to the clear objectives of financial reporting: the ability of the information to offer the investors the means to evaluate value, timeframe and security of future cash-flows that result from investing in a company's securities. The analysis of the relevant theoretical aspects identifies a theoretic assumption that seems to be the basis of the fair value paradigm. In conformity with this hypothesis of information aggregation, market prices cumulate in an efficient and theoretically unaltered manner, the consensus concerning the future expectations that shareholders have regarding the cash-flow typology which corresponds to the various assets or debts.

The change in paradigm change is determined by the assumed decisional relevance of market based evaluation. Both the FASB and IASB (International Accounting Standards Board) underline the capacity of market based evaluation in reflecting - in an efficient and theoretical unaltered manner - the consensus regarding market expectations in relation to future cash-flows. On the other hand, the opponents of fair value evaluation criticize the credibility of the data it generates, especially in the case of estimations based on models that are influenced by expectations and projections belonging to the management. It is important to underline here the fact that the implementation of fair value as an evaluation premise has long been the subject of fierce debates and controversies. The controversies regarding the accounting treatment of financial instruments using fair value have been also highlighted by the rejection of IAS 39 by the EU, due to both 
technical and conceptual implications. Apparently, the debate regarding the fair value of financial instruments is far from being over.

A historic retrospective helps us identify some landmarks regarding a process that can be considered a value based accounting (Ishikawa, 2005: 117). A first option of this new type of accounting - if we can call it that - was price changing accounting, which was intensely debated during the 1970's together with concepts regarding capital maintenance. Price modifying accounting was addressed to non-monetary assets, because changes in market prices could have been interpreted as a constant increase of the market prices of those individual assets. The second option is fair value accounting, which made its presence noticed at the end of the 80's, and which focuses on financial/derivative instruments: to be more precise, it considers the assets and debts instead of non-monetary assets, their values fluctuations and debts posing both positive and negative differences. The third option is the depreciation accounting, and is characterized by a significant loss of value for individual assets, due to declining profitability.

If the option of price modifying accounting implies aspects regarding the accounting treatment of real assets during the hyperinflation period of the 70's, one can say that the current fair value accounting implies accounting issues that can be met in markets that are exposed to the risk of share price fluctuations and interest rates fluctuations (Ishikawa, 2005). Even if all the three options presented in the previous paragraph aim bringing changes in market values, each of them tries to induce distinct, reciprocal changes as a pattern for price changes and economic foundation. In all options, however, despite aspects regarding financial transparency and the display of information about economic substance and financial risk, one must consider how to determine the equity/result (Ishikawa, 2005: 117). It is important to underline at this point, that each option was formed - from the historical point of view - in different economical and social contexts. A fourth option could focus on intangible assets. Clearly delimited from the tangible ones such as fixed assets, the intangible assets like goodwill, brand and know-how are also recognized at market value (current value) at the end of each financial exercise. Therefore, assets literally considered as having the capacity to generate future income cash-flows ("future assets" instead of "former assets") would be evaluated at their current value (Ishikawa, 2005: 118).

Also, due to the fact that the topic of evaluation is a very complex one, we have to mention an important fact: that fair value is the subject of a wide array of studies focused on the level of relevance that values have in financial reports. Important works that generate a comprehensive synthesis of this type of studies - reaching different, but never the less remarkable results - are the ones belonging to Holthausen and Watts (2001) and Barth et al. (2001). Both of these works take into consideration all the previous analysis regarding the relevance of the values used in financial reporting, and both try to identify the possible connections with the accounting regulation process. Holthausen and Watts (2001) start from the accounting theories, regulations and evaluations that are the basis of the interferences generated in the accounting regulation process by the results obtained through the research on the relevance of these values, finally concluding that the use of these results is, in fact, difficult.

In opposition to the previous idea, Barth et al. (2001) sustain that research based on analysis of the relevance that values used in financial reporting have, is meant to show to what extent the accounting values reflect information that is useful for investors, and provide answers to the questions of the major accounting regulating organizations. One of his arguments is that there are aspects regarding the relevance of using certain values that can be addressed through existing evaluation models. Studies that analyze such models through econometric methods supply regulating organisms with data which could not be obtained in a different manner. 
The category of studies that focus on the analysis of the level of re4levance of values used in financial reporting comprises a significant number of works dedicated to studying fair value in the case of financial instruments. We refer here to the fair value of financial debts and equity instruments, two of the most used instruments by banks and insurance companies (Barth, 1994; Ahmed and Takeda, 1995; Bernard et al., 1995; Petroni and Wahlen, 1995; Barth et al., 1996; Eccher et al., 1996; Nelson, 1996; Barth and Clinch, 1998). The main question that these studies want to answer is linked to the credible estimation of the fair value these securities have. The tendency of the obtained results is to show that investors find fair value estimations to be more relevant than historical cost ones, while the credibility of fair value estimations varies depending to the types of the securities and to the expectations of estimation errors.

At the same time, securities which are less traded on the market present a higher probability when it comes to evaluation errors in comparison to the ones that are traded more actively. Another characteristic issue is the one concerning the credibility of gains and losses generated by fair value; these in self having the capacity of affecting the overall credibility of fair value. Even if we imagined a utopist economy, where market are competitive (this assumes the lack of discrepancies between objective market values and current subjective ones), the concept of income or profit, as an expression of generating value, can easily create an error state (Rayman, 2007).

Fair value of bank loans a also an important topic for the accounting research literature, due to the doubtful credibility of estimations made by managers. This time too, the investors will perceive the fair value of bank loans as reflecting values with a superior relevance and credibility, in comparison with historical costs (Barth et al., 1996). The fact that bank managers are exposed to the temptation of using their influence when estimating fair values for bank loans, determined the need of an analysis of this aspect. From an overall point of view, the results indicate the fact that the managements' influence on fair value evaluation does not totally eliminate the relevance of values that have been determined in this manner.

The relevance of values obtained after fair value estimations is more controversial in the case of derivatives, due to the continuous development of the derivatives markets and of the technology used for making these estimations. Venkatachalam (1996) demonstrates that for this case also, from the investors' point of view, fair value of derivatives have a greater capacity for reflecting the economic truth than the national values have. Wong (2000) also demonstrates that estimation errors that are inherent to the fair value determination of derivatives, allow national values to incrementally express the information.

\section{Research methodology}

The employed research methodology mainly relies on literature review particularities. Similar to Matiş and Bonaci (2011), we develop a critical and evaluative account of what has been published within accounting research literature on fair value accounting, but while only considering studies that develop an empirical approach. Therefore, in accordance to literature review methodology imposed each considered study to be analyzed by looking at particular elements such as: question formation, identification of the relevance, assessment of quality, evidence summarization and interpretation of findings. Summary and synthesis was used in discussing the main results being obtained through the analyzed studies.

\section{Developing the analysis and discussing the obtained results}

An extremely important aspect that pointed out by the analysis of the historical evolution of fair value is that, as the development of different methods of evaluation imposed certain flexibility 
in standards, and implicitly, generated a higher probability of information manipulation, the regulating organisms tried to counteract this difficulty by soliciting as many information as possible, information that was meant to help create a faithful image for its users. In this regard, we would consider as useful a detailed analysis on the impact of supplied information upon the image perceived by its users, on which we could base the review of empirical studies.

The accounting research literature regards this issue from the point of view of various comparative analyses between the effects of recognitions that were mandatory in financial statements and recognitions of information that was disclosed on request. The nature of these studies and the difference they are meant to make is suitable for the development of empirical researches that require certain sustainable circumstances. Core (2001) makes a very comprehensive review of empirical studies that focus on information disclosure, showing that these are interconnected with studies focused on corporate governance and managerial stimulants.

Such a study that concentrates on financial instruments is the one of Ahmed et al. (2006). It analyzes the modality in which the evaluation of derivatives by investors depends on the situation in which fair value is recognized or when there are just some fragments of information regarding it. In the analysis, sustainable circumstances can only be found in American accounting regulations, the SFAS 133, prior to which accounting practices demanded only detailed information regarding fair value of the derivatives. After the introduction of SFAS 133, the recognition of these values is mandatory, thus offering an environment characterized by uniqueness (from a methodological point of view) and very suitable for a research of this kind.

Using a sample made up of banks that owned derivatives, both recognized and unrecognized at fair value prior to the implementation of SAFS 133, Ahmed et al. (2006) demonstrate the existence of significant evaluation coefficients acknowledged in the case of derivatives recognized at fair value, while the evaluation coefficients corresponding to unrecognized derivatives proved to be insignificant. Models that were used investigated the link between the values of entities and values of elements comprised in the financial reports of the analyzed entities. The second sample included banks that only owned derivatives unrecognized at fair value prior to the introduction of SFAS 133, therefore, detailed information regarding their values appeared only after the introduction of the regulation mentioned before, the results being the same as in the case of the previous sample. The contributions of this study consist in demonstrating the importance that SFAS $133 \mathrm{had}$ in the increase of transparency in reports regarding derivatives, and in recognizing and presenting information that before were not mandatory in financial reports, having significant implications on the relevancy of supplied information.

Theoretical studies regarding fair value were developed in the accounting research literature over the last two centuries while also allowing a vast expansion with a careful filtration of conceptual delimitations, but only recently they started to be accompanied by a series of empirical studies that explore links between evaluation options, market values and other related parameters (Gwillian and Jackson, 2008). Inflationist periods also stimulated accounting research focused on evaluation problems. Afterwards, the increasing spread of positive methodologies in the field of accounting and financial reporting, combined with a reactivation of the interest for the existing links between financial reporting and evaluation (through studies such as Ohlson 1991, 1995), have generated a significant increase in the number of empirical studies in this field.

Botosan et al. (2005) realize a concise summary of the research literature that deals with the relevance and credibility of fair value estimations used in financial reporting. At the same time, in their study - which represents an answer to the exposure draft (ED) issued by FASB on fair value evaluation - the authors warn us regarding the methodology used in existing studies, concerning the 
relevance of samples, profs and interpretations in these papers, and underline the fact that the majority of evidence that was brought by recent research comes from entities that have as main assets various financial instruments, i.e. financial institutions. Basing their opinion on studies by Barth, 1994, Petroni and Wahlen, 1995, Nelson, 1996 and others, Botosan et al. (2005) claim that:

Proofs show us that generally, fair values obtained from active markets are associated in a more credible manner to share prices, than the ones derived from using information obtained from markets that are less active or from various internal evaluation models of entities Botosan et al., 2005: 189).

Previous empirical studies on fair value evaluation are mostly limited to financial instruments. The results obtained so far support the increasing relevance of the fair value of shares (Petroni and Wahlen, 1995; Eccher et al., 1996; Nelson, 1996; Barth et al., 2001) and derivatives (Venkatachalam, 1996) owned by banks and insurance companies. Park and Park (1999) consider relevant the fair value recognition of shares available for sale according to SAFS 115. While all these studies focus on entities functioning in the financial sector, Simko (1999) does not identify any indication related to an increased relevance, according to presentations of SFAS 107 in a multiindustrial sample, the reason being attributed to the low significance of financial activities in the analyzed entities.

When it comes to other financial instruments such as loans granted by banks, results differ, this being a possible consequence of the lack of credibility due to internal confidential information. Previous research regarding the relevance of value (defined as the association between accounting values and share market values) have concentrated on determining the capacity of presentations at fair value in the banking system to generate informational content superior to historical costs. Testing and evaluating informational content assumes the ability to appreciate if a certain evaluation offers supplementary data in comparison to another evaluation, these two methods being often used when one or more evaluations are given or received, and another one is supplementary. (Biddle et al., 1995; Jennings, 1990). Biddle et al. (1995: 3) emphasize the fact that in the absence of an explicit test meant to determine whether or not a single value (fair value for example) is more, less or the same as informative than another one (historic cost for example), testing the increase of the informational content in the case of historic cost compared with fair value can imply a series o different results. Carrying out a test of the increased evolution of informative content in the case of fair value, can demonstrate that it can be more or less useful from the informational point of view than historical cost.

In the case of a sample made out of American banks, using information corresponding to years 1971-1990, Barth (1994) demonstrates that the fair value of share is incrementally associated with the price of the share of that bank after their historical cost analysis. When the analysis was carried out in the context of annual gains, the study shows mixed results regarding the possibility that unrecognizing the gains or losses from the value of the shares offers an incremental explicative power, which is relative to other components of the profit and loss account. A possible explanation of the confused conclusions resides in the fact that the estimations of profit or loss determined by the value of the shares contained too many errors of evaluation, in relation to the fluctuations of their market values.

Using the same database, Barth et al. (1995) confirm Barth's (1994) conclusions, and strengthen the explanations of errors in evaluation by reflecting the fact that evaluation based on fair values of net income represents a high volatility compared to the evaluation based on historical costs, but that incremental volatility is not reflected in the price of the bank's shares. Very important 
for the standard setting bodies in the banking industry are the conclusions of Barth et al. (1995), which state that banks violate more often the provisions related to fair value accounting than the one of historical costs, and that the major violations of rules in the case of fair value help predict the main violations of historical cost accounting, the price per share not having the ability of reflecting the risk increase from the regulations point of view.

Khurana and Kim (2003) also analyze the information relevance of fair value by examining the validity of the hypothesis according to which fair value has informational character that is superior to historical cost, as a financial reporting standard. Using fair value presentations that are supplied according to SFAS 107 and SFAS 115 by banking institutions from 1995 to 1998, they compare the explicative power of fair value and historical cost in reflection the value of equity instruments. For the sample that was used, Kuhrana and Kim (2003) were not able to identify perceptible differences from the point of view of the informational level supplied through the light of fair value measurements in relation to the ones using historical costs.

Another extremely relevant study when it comes to a retrospect in empirical studies is the one of Landsman (2007), which - starting from the great interested that American and international regulating organisms manifested in the elaboration of new financial reporting standards regarding recognition, evaluation and presentation of information related to financial instruments - realize a review of the literature from the capital market field, review which examines the informational utility that fair value accounting has for the users. On the whole, his results show that recognizing fair value and presenting information regarding it does have an informational value for investors, but at a level which depends directly from the dimension of errors of evaluation and from the estimation sources - in this case the management of the entities or external sources. His paper also offers a discussion focused o the implementation of fair value and the modality of determination of these value in the case of assets and debts.

Regarding the implications of some extreme parts in the evaluation process and capacity to improve the quality and usability of evaluations, proof shows mixed results. While Dietrich et al. (2000) succeed in demonstrating that that the level of credibility (their study focused on the evaluation of fixed assets evaluations) increases when fair values are determined by external evaluators and are audited by one of the big international firms, Barth and Clinch (1998) do not identify any difference regarding the credibility of the reevaluations made by internal and external auditors in the case of Australian firms. Proofs regarding the modality in which managers exercise their influence on fair value evaluations, like for example choosing the moment of recognition of losses generated by loans and the reported fair values for fixed assets before new loans were contracted, are also mixed. An extremely interesting study is the one of Bernard et al. (1995), which analyzed the impact of mark-to-market accounting using various data from Danish banks.

Denmark has very interesting research potential because regulating organism have used marking-to-market accounting for a long time. Bernard et al. (1995) conclude that despite the fact that there is proof of earnings owed to management, there is no clear evidence that the numbers determined by the application of marking-to-market model would be manipulated by management in order to avid constraints of the legal regulations. Furthermore, the marking-to-market model in the case of Danish banks demonstrates that net value of equity from the historical prices perspective, is more credible than the one from market values, in comparison with American banks. This suggests that using fair value accounting would have a positive outcome for American investors. Bernard et al. (1995) only found weak evidence of manipulations by Danish banks of fair value reporting in order to avoid legal provisions, but results indicate to some extent that managers tend to postpone the recognition of losses caused by loans. On the other side, Dietrich et al. (2000) found 
that mangers will use their influence when it comes to fixed assets reevaluations, so as to polish the reported earnings and to increase the values of evaluations prior to loan contracts.

From the category of studies that do not encourage the use of the fair value accounting concept (at least not in its international version) we must mention the one made by Kosmala (2005). The author frames the concept of fair value in the European context, analyzing the case of Poland by confronting the changes at the level of regulations (de jure analysis) with information obtained from a study made at the level of practitioners who were questioned and interviewed. The results indicate the existence of various linguistic and cultural impediments when this concept is transmitted, despite of the support offered by regulating organizations. The orientation of the analysis towards aspects connected to accountancy practice, allowed the identification of a lack of consensus regarding translation and grammatical structure of the fair value concept, also defining a lack of general familiarity with the essence of this concept, which originated from the West and was specifically built for the American and British context (Kosmala, 2005, p. 579). The author concludes that the Polish equivalent of this concept, a derivative of hybrid experiences, cannot be achieved outside Central and Eastern Europe, despite the indications from the EU.

We must also mention in this category the study of Sunder (2008, p. 111), which starts from the premise that the properties of many important evaluation rules can be quantified, analyzed and compared under the dome of a conceptual framework, so as to be useful for the decisional process. Thus, he combines theoretical analysis with econometric elements, visualizing the rules of evaluation as being econometric estimators of unobserved values of the ensemble. Implicitly, identifying that evaluation rule which registers the minimum of squared average of errors (related to the unobserved value of the ensemble of resources) is also, in his vision, an econometrical problem, and not a theoretical or principle one, depending on the dimensions of parameters - price volatility and evaluation errors - in an economy, industry sector or entity. In general, no evaluation rule, fair or not, does not dominate the others, and depending on parameters applied to the application environment, one can identify the most efficient evaluation rules (Sunder, 2008, p. 121).

\section{Concluding remarks}

It seems appropriate to conclude on all of these researches conducted in the accounting research literature by highlighting the role they play in the process of accounting regulation, the contribution they bring to identifying various aspects that derive from the subtleties of regulations, at the structuring of these aspects and to the obtainment of useful information. Researchers concerned with the evaluation field, are authors of unbiased analytical works, being at the same time familiar with the concepts underlying financial reporting. While regulating organisms have a wider responsibility, which must take into consideration the multiple aspects that lead to the elaboration of a standard, the research activities are the one which provide necessary information for that standardization process and posses the necessary questions that final standard needs to address. Fair value is a key topic on which the accounting research literature - already vast and but still growing - can bring its contribution, the truth being that this concept affects a series of major projects such those relating to incomes, debts insurance contracts, financial instruments, conceptual framework, and others.

\section{Acknowledgements}

This work was supported by CNMP, project number 92-085/2008. The project is entitled "Developing a functional model for optimizing the national strategy regarding financial reporting within Romanian private sector entities". 


\section{References}

1. Ahmed A.S., Takeda C., 1995. Stock market valuation of gains and losses on commercial banks investment securities: an empirical analysis, Journal of Accounting and Economics, vol. 20, p. 207 225

2. Barlev B., Haddad J.R., 2003. Fair value accounting and the management of the firm, Critical Perspectives on Accounting, vol. 14, no. 4, p. 383-415

3. Barth M. E., 1994. Fair value accounting: evidence from investment securities and market valuation, The Accounting Review, vol. 69, no. 1, p. 1-25

4. Barth M. E., Landsman W. R., Wahlen J. M., 1995. Fair Value Accounting: Effects on Banks' Earnings Volatility, Regulatory Capital, and Value of Contractual Cash Flows, Journal of Banking and Finance, vol. 19, p. 577-605

5. Barth M.E., Beaver W.H., Landsman W.R., 1996. Value-relevance of banks fair value disclosures under SFAS 107, The Accounting Review, vol. 71, p. 513-537

6. Barth M., Clinch G., 1998. Revalued financial, tangible, and intangible assets: Associations with share prices and non-market-based value estimates, Journal of Accounting Research, vol. 36(Suppl.), p. 199-233

7. Barth M.E., Beaver W. H., Landsman W.R., 2001. The relevance of the value relevance literature for financial accounting standard setting: another view, Journal of Accounting and Economics, vol. 31, p. 77-104

8. Bernard V. L., Merton R. C., Palepu K. G., 1995. Mark-to-market accounting for banks and thrifts: Lessons from the Danish experience, Journal of Accounting Research, vol. 33, p. 1-32

9. Biddle G., Seow G., Siegel A., 1995. Relative versus incremental information content, Contemporary Accounting Research, vol. 12, no. 1, p. 1-23

10. Botosan C.A., Beatty A.L., Hopkins P.E., Nelson K.K., Venkatachalam, M., 2005. Response to the FASB's Exposure Draft on Fair Value Measurements, Accounting Horizons, vol. 19, no.3, p.187-196

11. Dietrich J., Harris M., Muller K., 2000. The reliability of investment property fair value estimates, Journal of Accounting and Economics, vol. 30, no. 2, p. 125-158

12. Eccher E., Ramesh K., Thiagarajan R., 1996. Fair value disclosures by BHCs, Journal of Accounting and Economics, vol. 22, no. 1-3, p. 79-117

13. Holthausen R.W., Watts R.L., 2001. The relevance of the value-relevance literature for financial accounting standard setting, Journal of Accounting and Economics, vol. 31, p. 3-75

14. Ishikawa J., 2005. A social science of contemporary value-based accounting: economic foundations of accounting for financial instruments, Critical Perspectives on Accounting, vol. 16, p. 115-136

15. Jennings R., 1990. A Note on Interpreting 'Incremental Information Content', The Accounting Review, vol 65, p. 925-932

16. Khurana I.K., Kim M.-S., 2003. Relative value relevance of historical cost vs. fair value: Evidence from bank holding companies, Journal of Accounting and Public Policy, vol. 22, p. 19-42

17. Kosmala K., 2005. True and Fair View or rzetelny i jasny obraz1? A Survey of Polish Practitioners, European Accounting Review, vol. 14, no. 3, p. 579-602

18. Landsman W.R., 2007. Is fair value accounting information relevant and reliable? Evidence from capital market research, Accounting and Business Research Special Issue: International Accounting Policy Forum, p. 19-30 
19. Matiş D., Bonaci C. G., 2008. Fair Value Accounting for Financial Instruments - Conceptual Approach and Implications, Timisoara Journal of Economics, Timisoara, pp. 191-206

20. Matiş D., Bonaci C.G., 2011. Recent developments of the financial reporting model: theoretical studies in review, Working paper presented at the European Integration - New Challenges International Conference, Oradea, May 2011

21. Nelson K. K., 1996. Fair value accounting for commercial banks: An empirical analysis of SFAS No. 107, The Accounting Review, vol. LXXI (April), p. 161-182

22. Ohlson J., 1991. Earnings, book value and dividends in security valuation., Working Paper. USA: University of Columbia

23. Ohlson J., 1995. Earnings, book values, and dividends in equity valuation, Contemporary Accounting Research, vol. 11, p. 661-687

24. Petroni K. R., Wahlen J. M., 1995. Fair values of equity and debt securities and share prices of property-liability insurers, Journal of Risk and Insurance, vol. 62, no. 4, p. 719-737

25. Rayman R.A., 2007. Fair value accounting and the present value fallacy: The need for an alternative conceptual framework, The British Accounting Review, vol. 39, p. 211-225

26. Simko P., 1999. Financial instruments fair values and nonfinancial firms, Journal of Accounting, Auditing, and Finance, vol. 14, no. 1, p. 247-274

27. Sunder S., 2008. Econometrics of Fair Values, Accounting Horizons, vol. 22, no. 1, p. 111-125

28. Venkatachalam M., 1996. Value-Relevance of Banks' Derivatives Disclosures, Journal of Accounting and Economics, vol. 22, p. 327-355

29. Wong M.H.F., 2000. The association between SFAS 119 derivatives disclosures and the foreign exchange risk exposure of manufacturing firms, Journal of Accounting Research, vol. 38, p. 387417 